\title{
Intersection of historical museum collections and modern systematics: a relict population of the Arctic nudibranch Dendronotus velifer G.O. Sars, 1878 in a Swedish fjord
}

\author{
Kennet Lundin ${ }^{1,2}$, Tatyana Korshunova ${ }^{3,4}$, Klas Malmberg 5 , Alexander Martynov ${ }^{4,6}$ \\ ${ }^{1}$ Gothenburg Natural History museum, Box 7283, S-40235, Gothenburg, Sweden, \\ ${ }^{2}$ Gothenburg Global Biodiversity Centre, Box 461, S-40530, Gothenburg, Sweden, \\ ${ }^{3}$ Koltzov Institute of Developmental Biology, Vavilova str. 26, 119334 Moscow, Russia, \\ ${ }^{4}$ Zoological Museum of the Moscow State University, Bolshaya Nikitskaya Str. 6125009 Moscow, Russia, \\ ${ }^{5}$ Aquatilis, Nostravägen 11, S-417 43, Gothenburg, Sweden. \\ ${ }^{6}$ E-mail: martynov@zmmu.msu.ru \\ All authors contributed equally to this work
}

Keywords: biological conservation, biogeographic ranges, integrative taxonomy, invertebrates, molecular species delineation, Mollusca, museum collections

\begin{abstract}
Based on morphological, bathymetric and molecular data comparing recently collected Arctic and North Atlantic specimens with morphological and bathymetrical data on historical museum specimens, a unique relict population of the deep-water mollusc Dendronotus velifer G.O. Sars, 1878 (Gastropoda: Nudibranchia) is shown to have existed in the deepest section of the Swedish Gullmar Fjord (the only true silled fjord in Sweden) at least until the middle of the 20th century. This population is more than $1500 \mathrm{~km}$ away from the nearest point in the species' distributional range in the Arctic Ocean today. Using an integrative approach incorporating the data mentioned above, including genetic distances, from recently collected specimens taken from the Arctic Ocean, $D$. velifer is validated and its species status is restored, for the first time in more than a century after being regarded as a junior synonym of $D$. robustus. The bathymetric data for historical and recently collected specimens of $D$. velifer demonstrate significant differences compared to the shallow-water species D. robustus. The findings support the necessity of a stronger protection for the unique marine habitats of the Gullmar Fjord.
\end{abstract}

\section{Contents}

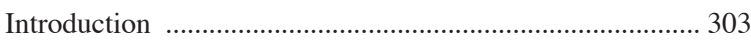

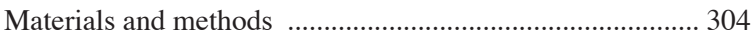

Historical museum specimens ..................................... 304

Specimens collected on recent expeditions ..................... 306

Morphological analysis .................................................. 306

Molecular and statistical analyses ................................ 306

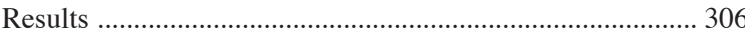

Molecular analysis of Arctic material of Dendronotus

robustus and D.velifer ..................................................... 306

Statistical analysis of the bathymetric distribution ........ 309

Discussion ......................................................................... 310

Integration of molecular and morphological data .......... 311

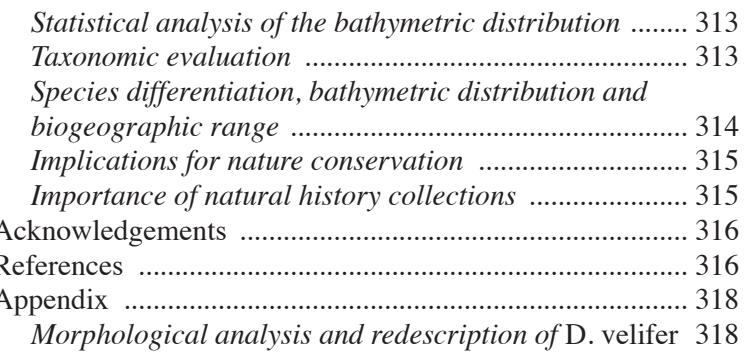

\section{Introduction}

An accurate taxonomy is indispensable for evaluating the conservation status and biogeographic pattern of species (Bickford et al., 2006; Martynov et al., 2017). Modern molecular analyses are able to reveal considerable inconsistencies within morphology-based systematics and thus may have a direct influence on the conservation status of a species and on the perception of its distributional range. A potentially threatened species cannot be properly understood, or even recognised, without a thorough taxonomic background study. While for large well-known vertebrate animals a taxonomic placement is usually well established today, this is not the same for numerous invertebrates, especially marine ones. An incorrect taxonomy may affect the estimation of the actual number of species in a protected area, and thus may cause an underestimation of the conservation needs of that area.

Here we present a case from an outstanding group of marine invertebrates, the nudibranch molluscs (Gastropoda: Opisthobranchia), and discuss the importance of a correct taxonomic basis for the conservation 
perspectives and evaluation of biogeographic patterns within Scandinavian fjords.

Nudibranch molluscs are important model subjects for various disciplines, including phylogenetics, neurophysiology and also the emerging field of marine natural products (Nuzzo et al., 2012; Goodheart et al., 2015; Katz, 2016). They are now routinely included in wellillustrated field guides (Picton and Morrow, 1994; Malmberg and Lundin, 2015; Hayward and Ryland, 2017) and owing to their attractiveness they have recreational importance in national parks and other conservation areas (e.g., Bertsch, 2014; Garcia-Mendéz and Camacho-Garcia, 2016; Mehrotra and Scott, 2016; Nimbs et al., 2016). The species of the nudibranch genus Dendronotus occur in the Northern European and Arctic seas, generally on rocky and stony habitats in shallow waters less than $50 \mathrm{~m}$ deep (Thompson and Brown, 1984; Thollesson, 1998; Korshunova et al., 2016). Most have relatively slender bodies and they feed on hydroids. One of the most notable exceptions is a species that inhabits soft bottoms at depths greater than $50 \mathrm{~m}$, which has a relatively broad body and an omnivorous diet (Roginskaya, 1987). This species has generally been called Dendronotus robustus Verrill, 1870, and has been assessed as having a very broad circumpolar distribution (Ekimova et al., 2015). In the northeast Atlantic Ocean, it occurs from the Vega archipelago in Hordaland on the northwestern Norwegian coast (Evertsen and Bakken, 2005), northwards to the Barents Sea in the Arctic Ocean, and across to the Kara Sea and the White Sea in Russia (Martynov and Korshunova, 2011). On the northwestern side of the Atlantic Ocean it occurs from Cape Cod to Greenland, and to the Bering Strait (Verrill, 1870; G.O. Sars, 1878; Odhner, 1907, 1939; Ekimova et al., 2015). On Arctic latitudes, as in the Barents Sea, it occurs in relatively shallow depths, but in the southernmost parts of its range it occurs at greater depths.

A species that is similar to D. robustus apparently had an isolated population in the Gullmar Fjord on the Swedish west coast at least until the early 1940s. This southernmost occurrence has not been appropriately described in the literature. There are no other reports or findings from any other areas in Swedish waters or the British Isles, where the nudibranch fauna is now well known (e.g., Thompson and Brown, 1984; Picton and Morrow, 1994; Malmberg and Lundin, 2015). The nearest present occurrence is on the northwestern Norwegian coast, some $1500 \mathrm{~km}$ from of the Gullmar Fjord, except for two historical findings - one specimen from the innermost part of the Oslo Fjord in 1912, and one specimen from the Hardanger Fjord, south of Ber- gen, collected sometime between 1860 and 1920. Both of these specimens are deposited at the Oslo Museum of Natural History. Dendronotus robustus was listed for Denmark (Jensen and Knudsen, 1995), but without a description that could confirm the identification. The isolated population in the Gullmar Fjord was apparently rather abundant if one considers how many specimens collected in the late 1800s were deposited at the Gothenburg Natural History Museum (GNM) and the Swedish Natural History Museum (NRM).

To re-evaluate the taxonomic status of the population in the Gullmar Fjord, we use an integrated analysis applying morphological and molecular methods for both very shallow water populations and the deepwater specimens currently known as "D. robustus" from across almost its entire geographic range. We compare the bathymetric distribution of the historical specimens from Gullmar Fjord with both shallowwater and deep-water populations using a statistical test. The reliability of an integrated molecular and morphological approach has recently been proved by the discovery in Norway and Great Britain of a large new nudibranch species within one of the world's best studied European marine faunas (Korshunova et al., 2017). The resultant conclusions are highly relevant from both biogeographic and conservation perspectives, and important for the ongoing discussion regarding the conservation of the Gullmar Fjord.

In the present study we show that there are two distinct species previously mixed up under the name " $D$. robustus" (e.g. Ekimova et al., 2015). These species are D. robustus Verrill, 1870 and D. velifer G.O. Sars, 1878. According to our present analysis the Gullmar Fjord accommodates the species D. velifer G.O. Sars, 1878 , and not the true D. robustus. The synonymy of the latter species, plus the designation of a lectotype, and a revised morphological description, are given in the Appendix to this paper.

\section{Materials and methods}

\section{Historical museum specimens}

A total of 117 specimens of the Dendronotus robustus species complex (Table 1) from the Gothenburg Natural History Museum (GNM), the Swedish Museum of Natural History, and the Oslo Natural History Museum (NHM-UIO) were investigated, including a study of both external and internal features. The majority of the specimens had been examined and determined as Den- 

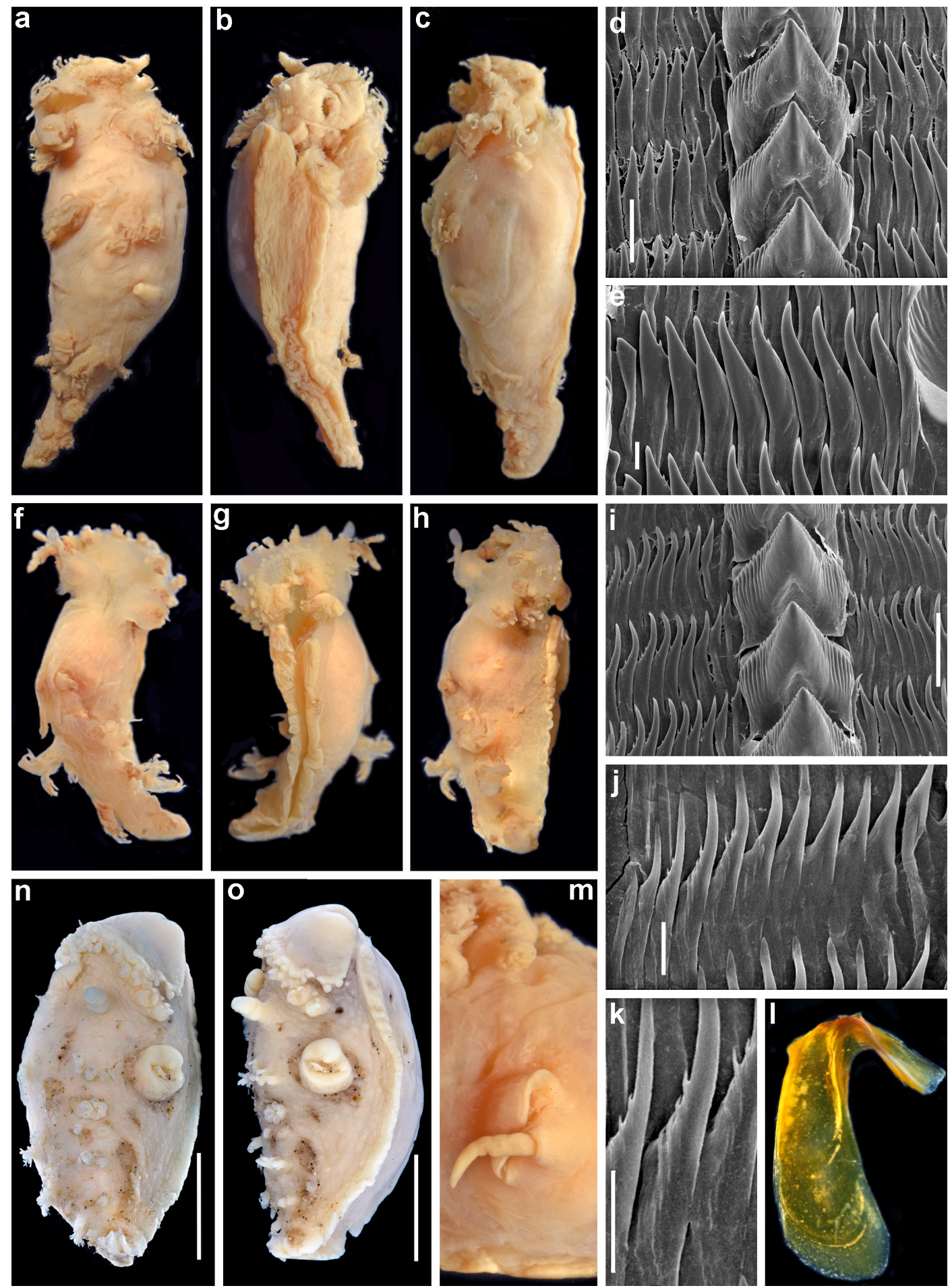

Figure 1. Dendronotus velifer, two historical specimens from the Gullmar Fjord. a-c: habit of specimen $26 \mathrm{~mm}$ in length (GNM 3026); f-h: habit of specimen $13.5 \mathrm{~mm}$ in length, dorsal, ventral and lateral views respectively (GNM 3027); . d-e: radula of specimen GNM 3026; i-k: radula of specimen GNM 3027, central and lateral teeth respectively; 1, jaw; n, o: lectotype, Barents Sea, Vadsø, NHM-UIO nr. 16174. m: genital openings and copulative apparatus. Scale bars: d, i: $100 \mu \mathrm{m}$; e, j, k: $30 \mu \mathrm{m}$; n, o: 5 mm. Photographs by Tatiana Korshunova (a-h, m) and Karsten Sund (n, o). 
dronotus robustus by the nudibranch specialist Nils Odhner between the 1910s to the 1930s. Five of the specimens from the Gothenburg Natural History Museum were sent as loan to the Zoological Museum in Moscow for morphological investigation. Two specimens (GNM 3026 and 3027) were dissected and SEM-studies of their radula were performed (Figure 1, Table 1). Additionally, AM checked all previously identified as D. robustus specimens while he visited GNM in August 2017.

\section{Specimens collected on recent expeditions}

A total of 15 specimens of the Dendronotus robustus species complex were collected alive during marine biological expeditions in the Barents, Kara, and Laptev seas (Table 2; Figs. 2,3) in this study and earlier. These specimens were all deposited in the Zoological Museum of Moscow State University (ZMMU, Op-296, Op-343, Op-344, Op-348, Op-390, Op-391, Op-392, Op-393, Op-546, Op-547).

\section{Morphological analysis}

The external and internal morphology was studied under a stereomicroscope and using a full-frame digital camera (Nikon D-810). The buccal mass of each specimen was extracted and processed in $10 \%$ sodium hypochlorite solution to extract the radula and the jaws. The jaws of each species were analysed under a stereomicroscope and then photographed. The radulae were coated and examined and photographed using a scanning electron microscope (CamScan). The reproductive systems were also examined using the stereomicroscope.

\section{Molecular and statistical analyses}

All 15 specimens of the Dendronotus robustus species complex from the Barents, Kara, and Laptev seas were sequenced in this study and earlier for the mitochondrial genes cytochrome c oxidase subunit I (COI) and $16 \mathrm{~S}$, and sequences of one specimen were obtained from GenBank (see Table 2 for list of samples, localities, and voucher references). No historical museum specimens were able to be sequenced because their extracted DNA was in a degraded state.

Small pieces of foot tissue were used for DNA extraction with Diatom ${ }^{\mathrm{TM}}$ DNA Prep 100 kit by Isogene Lab, according to the manufacturer's protocols. Extracted DNA was used as a template for the amplification of partial sequences of the COI and $16 \mathrm{~S}$. The primers that were used for amplification were LCO1490
(GGTCAACAAATCATAAAGATATTGG (Folmer et al., 1994)); HCO2198 (TAAACTTCAGGGTGACCAAAAAATCA (Folmer et al., 1994)); 16SarL (CGCCTGTTTAACAAAAACAT (Palumbi et al., 2002)); 16SR (CCGRTYTGAACTCAGCTCACG (Puslednik and Serb 2008). Polymerase chain reaction (PCR) amplifications were carried out in a $20 \mu \mathrm{L}$ reaction volume, which included $4 \mu \mathrm{L}$ of $5 x$ Screen Mix (Eurogen Lab), $0.5 \mu \mathrm{L}$ of each primer (10 $\mu \mathrm{M}$ stock), $1 \mu \mathrm{L}$ of genomic DNA, and $14 \mu \mathrm{L}$ of sterile water. The amplification of COI was performed with an initial denaturation for $1 \mathrm{~min}$ at $95^{\circ} \mathrm{C}$, followed by 35 cycles of $15 \mathrm{sec}$ at $95^{\circ} \mathrm{C}$ (denaturation), $15 \mathrm{sec}$ at $45^{\circ} \mathrm{C}$ (annealing temperature), and $30 \mathrm{sec}$ at $72^{\circ} \mathrm{C}$, with a final extension of 7 min at $72{ }^{\circ} \mathrm{C}$. The $16 \mathrm{~S}$ amplification began with an initial denaturation for $1 \mathrm{~min}$ at $95^{\circ} \mathrm{C}$, followed by 40 cycles of $15 \mathrm{sec}$ at $95^{\circ} \mathrm{C}$ (denaturation), $15 \mathrm{sec}$ at $52^{\circ} \mathrm{C}$ (annealing temperature), and $30 \mathrm{sec}$ at $72^{\circ} \mathrm{C}$, with a final extension of $7 \mathrm{~min}$ at $72^{\circ} \mathrm{C}$. Sequencing for both strands proceeded with the ABI PRISM ${ }^{\circledR}$ BigDye $^{\mathrm{TM}}$ Terminator v. 3.1. Sequencing reactions were analysed using an Applied Biosystems 3730 DNA Analyzer. Protein-coding sequences were translated into amino acids for confirmation of the alignment. All sequences were deposited in GenBank (Table 2).

Original data and publicly available sequences were aligned with the MUSCLE algorithm (Edgar 2004). Separate analyses were conducted for the data sets; the resulting alignments being $658 \mathrm{bp}$ for COI, $443 \mathrm{bp}$ for 16S. The program Mega7 (Kumar et al., 2016) was used to calculate the uncorrected $\mathrm{p}$-distances between all the sequences and distances within and between groups.

To evaluate the genetic distribution of the different haplotypes the haplotype network for both the COI and for $16 \mathrm{~S}$ genes were reconstructed using the Population Analysis with Reticulate Trees (PopART, http:// popart.otago.ac.nz) with the TCS network method. Usefulness of the haplotype network analysis for the delineation of the nudibranch species have been demonstrated recently (e.g. Padula et al., 2014; Furfaro et al., 2016) Bathymetric data were evaluated statistically using nonparametric Mann-Whitney rank sum tests.

\section{Results}

Molecular analysis of Arctic material of Dendronotus robustus and Dendronotus velifer

The present molecular analysis shows that there are two distinct species under the name Dendronotus robustus, 
Table 1. Historical specimens of Dendronotus velifer G.O. Sars, 1878 from Swedish and Norwegian museums.

\begin{tabular}{|c|c|c|c|c|c|c|c|}
\hline Museum & $\begin{array}{l}\text { Museum } \\
\text { registration } \\
\text { number }\end{array}$ & $\begin{array}{l}\text { Number } \\
\text { of speci- } \\
\text { mens }\end{array}$ & Locality & Date & $\begin{array}{l}\text { Depth, } \\
\text { m }\end{array}$ & Collector & $\begin{array}{l}\text { Previous identification } \\
\text { and name of identifier }\end{array}$ \\
\hline \multirow[t]{17}{*}{$\begin{array}{l}\text { Gothenburg Natural } \\
\text { History Museum }\end{array}$} & $\begin{array}{l}\text { Gastropoda } \\
3024\end{array}$ & 11 & Skår, Gullmar Fjord & $1887-07-01$ & $100-116$ & A. Stuxberg & D. robustus by N. Odhner \\
\hline & $\begin{array}{l}\text { Gastropoda } \\
3025\end{array}$ & 8 & Skår, Gullmar Fjord & $1887-07-22$ & $100-116$ & A. Stuxberg & D. robustus by N. Odhner \\
\hline & $\begin{array}{l}\text { Gastropoda } \\
3026, \\
\text { dissected }\end{array}$ & 1 & $\begin{array}{l}\text { Alsbäck, Gullmar } \\
\text { Fjord }\end{array}$ & $1887-07-17$ & $100-118$ & A. Stuxberg & D. robustus by N. Odhner \\
\hline & $\begin{array}{l}\text { Gastropoda } \\
3027, \\
\text { dissected }\end{array}$ & 1 & $\begin{array}{l}\text { Alsbäck, Gullmar } \\
\text { Fjord }\end{array}$ & $1887-07-11$ & $100-118$ & A. Stuxberg & D. robustus by N. Odhner \\
\hline & $\begin{array}{l}\text { Gastropoda } \\
3028\end{array}$ & 2 & $\begin{array}{l}\text { Finsbo udde, } \\
\text { Gullmar Fjord }\end{array}$ & $1889-07-18$ & - & A. Stuxberg & D. robustus by N. Odhner \\
\hline & $\begin{array}{l}\text { Gastropoda } \\
3029\end{array}$ & 6 & $\begin{array}{l}\text { Finsbo udde, } \\
\text { Essevik, Gullmar } \\
\text { Fjord }\end{array}$ & $1887-06-22$ & - & A. Stuxberg & D. robustus by N. Odhner \\
\hline & $\begin{array}{l}\text { Gastropoda } \\
3030\end{array}$ & 7 & $\begin{array}{l}\text { Skåreskär, } \\
\text { Gullmar Fjord }\end{array}$ & $1887-06-23$ & $100-116$ & A. Stuxberg & D. robustus by N. Odhner \\
\hline & $\begin{array}{l}\text { Gastropoda } \\
3031\end{array}$ & 3 & $\begin{array}{l}\text { Skåreskär, } \\
\text { Gullmar Fjord }\end{array}$ & $1887-06-28$ & $90-116$ & A. Stuxberg & D. robustus by N. Odhner \\
\hline & $\begin{array}{l}\text { Gastropoda } \\
3032\end{array}$ & 4 & $\begin{array}{l}\text { Skåreskär, } \\
\text { Gullmar Fjord }\end{array}$ & $1887-06-29$ & $90-116$ & A. Stuxberg & D. robustus by N. Odhner \\
\hline & $\begin{array}{l}\text { Gastropoda } \\
3033\end{array}$ & 1 & $\begin{array}{l}\text { Skåreskär, } \\
\text { Gullmar Fjord }\end{array}$ & $1887-06-30$ & $90-116$ & A. Stuxberg & D. robustus by N. Odhner \\
\hline & $\begin{array}{l}\text { Gastropoda } \\
3034\end{array}$ & 1 & Gullmar fjord & $1887-07-28$ & - & A. Stuxberg & D. robustus by N. Odhner \\
\hline & $\begin{array}{l}\text { Gastropoda } \\
3035\end{array}$ & 8 & $\begin{array}{l}\text { Gullmars-viken, } \\
\text { Gullmar Fjord }\end{array}$ & $1889-08-01$ & $35-90$ & A. Stuxberg & D. robustus by N. Odhner \\
\hline & $\begin{array}{l}\text { Gastropoda } \\
3036\end{array}$ & 2 & $\begin{array}{l}\text { Darns-huvud, } \\
\text { Gullmar Fjord }\end{array}$ & $1889-07-11$ & $60-85$ & A. Stuxberg & D. robustus by N. Odhner \\
\hline & $\begin{array}{l}\text { Gastropoda } \\
3037\end{array}$ & 1 & $\begin{array}{l}\text { Hällebäck, } \\
\text { Gullmar Fjord }\end{array}$ & 1889-07-08 & $60-110$ & A. Stuxberg & D. robustus by N. Odhner \\
\hline & $\begin{array}{l}\text { Gastropoda } \\
3652\end{array}$ & 2 & Skår, Gullmar Fjord & $1887-07-01$ & $100-116$ & A. Stuxberg & D. robustus by N. Odhner \\
\hline & $\begin{array}{l}\text { Gastropoda } \\
3038\end{array}$ & 6 & $\begin{array}{l}\text { Kristine-berg, } \\
\text { Gullmar Fjord }\end{array}$ & $\begin{array}{l}\text { September - } \\
\text { October } 1905\end{array}$ & - & $\begin{array}{l}\text { L.A } \\
\text { Jägerskiöld }\end{array}$ & D. robustus by N. Odhner \\
\hline & $\begin{array}{l}\text { Gastropoda } \\
3652\end{array}$ & 3 & $\begin{array}{l}\text { Skår, } \\
\text { Gullmar Fjord }\end{array}$ & 1917-07-01 & $90-116$ & R. Wahrberg & $\begin{array}{l}\text { D. velifer by K. Lundin } \\
\text { April } 2017\end{array}$ \\
\hline \multirow{2}{*}{$\begin{array}{l}\text { Swedish Museum } \\
\text { of Natural History }\end{array}$} & 197 & 10 & Gullmar Fjord & July 1889 & $70-90$ & C. Aurivillius & D. robustus by N. Odhner \\
\hline & 198 & 4 & $\begin{array}{l}\text { Saltkälle-fjorden, } \\
\text { innermost section of } \\
\text { the Gullmar Fjord }\end{array}$ & August 1894 & - & - & D. robustus by N. Odhner \\
\hline
\end{tabular}




\begin{tabular}{|c|c|c|c|c|c|c|c|}
\hline Museum & $\begin{array}{l}\text { Museum } \\
\text { registration } \\
\text { number }\end{array}$ & $\begin{array}{l}\text { Number } \\
\text { of speci- } \\
\text { mens }\end{array}$ & Locality & Date & $\begin{array}{l}\text { Depth, } \\
\text { m }\end{array}$ & Collector & $\begin{array}{l}\text { Previous identification } \\
\text { and name of identifier }\end{array}$ \\
\hline & 199 & 1 & Gullmar Fjord & $\begin{array}{l}\text { Not stated, late } \\
1800 \mathrm{~s}\end{array}$ & - & - & D. robustus by N. Odhner \\
\hline & 200 & 4 & Gullmar Fjord & 1893,1896 & - & - & D. robustus by N. Odhner \\
\hline & 201 & 1 & $\begin{array}{l}\text { Flatholmen, } \\
\text { Gullmar Fjord }\end{array}$ & August 1891 & - & O. Carlgren & D. robustus by N. Odhner \\
\hline & 202 & 9 & Skår, Gullmar Fjord & 1895 & & N. Odhner & D. robustus by N. Odhner \\
\hline & $8072(1116)$ & 1 & Gullmar Fjord & $1908-08-17$ & _ & N. Odhner & D. robustus by N. Odhner \\
\hline & $8682(1435)$ & 1 & $\begin{array}{l}\text { Kristine-berg marine } \\
\text { biological station, } \\
\text { Gullmar Fjord }\end{array}$ & July 1920 & - & N. Odhner & D. robustus by N. Odhner \\
\hline & $8968(1455)$ & 1 & $\begin{array}{l}\text { Kristine-berg Marine } \\
\text { Biological Station, } \\
\text { Gullmar Fjord }\end{array}$ & July 1913 & - & N. Odhner & D. robustus by N. Odhner \\
\hline & $10595(1813)$ & 1 & $\begin{array}{l}\text { Saltkälle-fjorden } \\
\text { innermost part of } \\
\text { the Gullmar Fjord }\end{array}$ & 1941 & 53 & S. Bock & D. robustus by N. Odhner \\
\hline & $10599(1817)$ & 1 & $\begin{array}{l}\text { Smör-kullen, } \\
\text { Gullmar Fjord }\end{array}$ & 1941 & $40-71$ & S. Bock & D. robustus by N. Odhner \\
\hline & $10600(1818)$ & 1 & $\begin{array}{l}\text { Smör-kullen, } \\
\text { Gullmar Fjord }\end{array}$ & 1941 & $40-71$ & S. Bock & D. robustus by N. Odhner \\
\hline & $10676(1854)$ & 1 & $\begin{array}{l}\text { Smör-kullen, } \\
\text { Gullmar Fjord }\end{array}$ & 1941 & $40-71$ & S. Bock & D. robustus by N. Odhner \\
\hline \multirow[t]{8}{*}{$\begin{array}{l}\text { Oslo Natural } \\
\text { History Museum }\end{array}$} & 16174 & 10 & Vads $\varnothing$ & - & $70-180$ & G.O. Sars & $\begin{array}{l}\text { G.O. Sars original } \\
\text { identification }\end{array}$ \\
\hline & & & & & & & D. robustus by N. Odhner \\
\hline & 16175 & 2 & Troms $\varnothing$ & - & - & M. Sars & $\begin{array}{l}\text { M. Sars original } \\
\text { identification }\end{array}$ \\
\hline & & & & & & & D. robustus by N. Odhner \\
\hline & 16176 & 1 & $\begin{array}{l}\text { Sunde, } \\
\text { Hardanger Fjord }\end{array}$ & - & - & G.O. Sars & $\begin{array}{l}\text { G.O. Sars original } \\
\text { identification }\end{array}$ \\
\hline & & & & & & & D. robustus by N. Odhner \\
\hline & 16177 & 1 & $\begin{array}{l}\text { Oslo Fjord, } \\
\text { Bunde-fjord }\end{array}$ & $\begin{array}{l}\text { winter-spring } \\
1912\end{array}$ & - & G.O. Sars & $\begin{array}{l}\text { G.O. Sars original } \\
\text { identification }\end{array}$ \\
\hline & & & & & & & D. robustus by N. Odhner \\
\hline
\end{tabular}

corresponding to D. robustus Verrill, 1870 and $D$. velifer G.O. Sars, 1878. Of the sampled specimens, 11 belonged to the former species and five to the latter. Minimal uncorrected p-distances for the COI gene are significantly different between both species, with a range of $8.74 \% \pm 1.24 \%$. Distances within D. robustus group are within $0.71 \%$. Distances within D. velifer group are up to $0.54 \%$, but distances between D. robustus and D. velifer groups reach 9.34\%. Results obtained by PopART both for the COI and for $16 \mathrm{~S}$ genes showed 

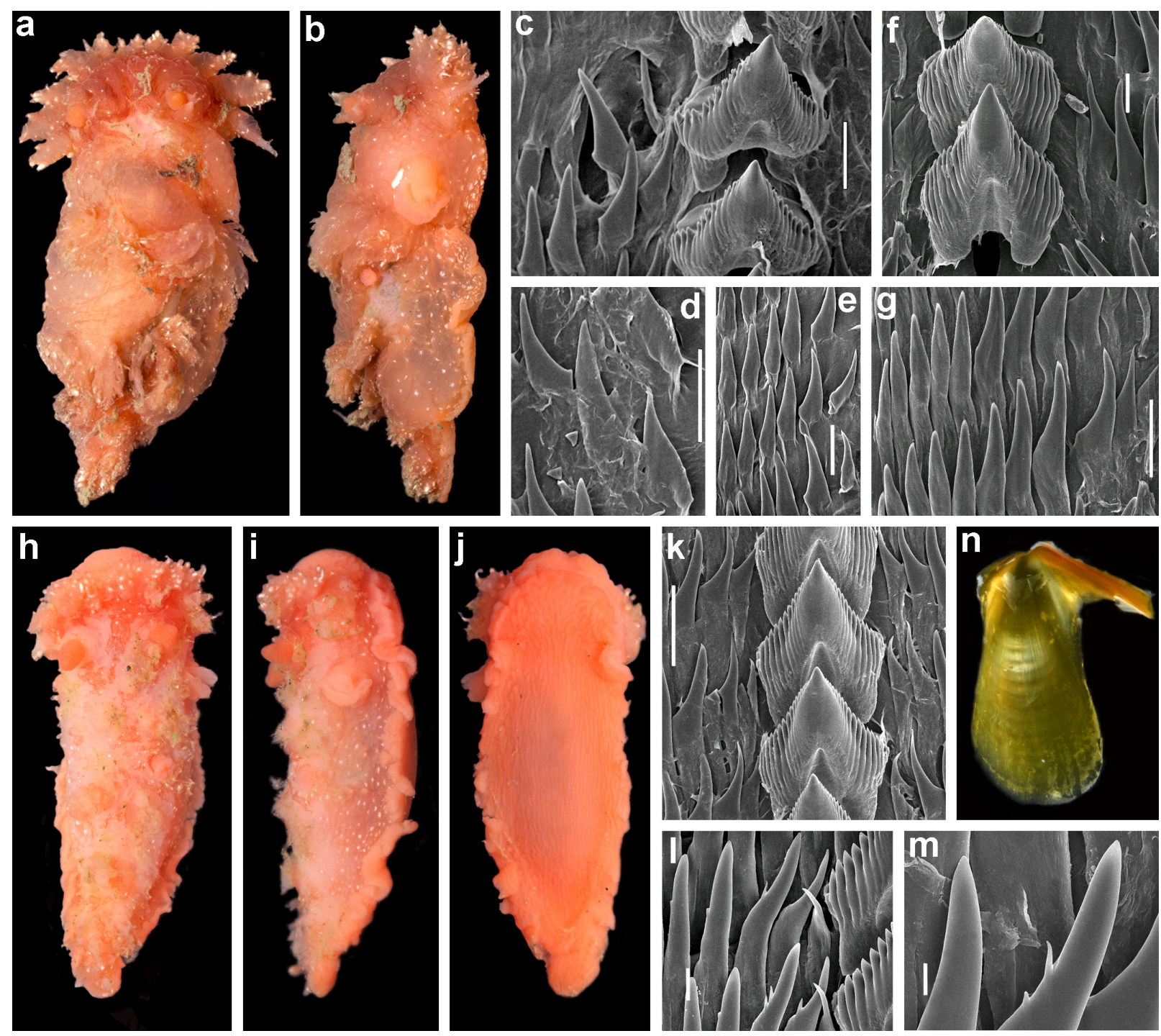

Figure 2. Recently collected Dendronotus velifer specimens from the Arctic, which were utilised for the molecular study. a-b: specimen 49 mm in length (preserved), Laptev Sea (ZMMU Op-546), dorsal and lateral views; h-j: specimen 23 mm in length preserved, Kara Sea (ZMMU Op-348), dorsal, lateral and ventral views respectively. c-g: internal characters of the specimen in a-b: radula, central and lateral teeth, and lateral teeth only respectively; $\mathrm{n}$ : jaw $9.6 \mathrm{~mm}$ in length; $\mathrm{k}-\mathrm{m}$ : internal characters of the specimen in $\mathrm{h}-\mathrm{j}$ : radula, central and lateral teeth and lateral teeth only, respectively. Scale bars: c, d, e, g, k: $100 \mu \mathrm{m}$; $: 50 \mu \mathrm{m} ; 1: 20 \mu \mathrm{m}$; m: $10 \mu \mathrm{m}$. Photographs of specimens (a, b, h-j) by O. Zimina.

a network of haplotypes that clearly clustered into two groups coincident with the species $D$. robustus and $D$. velifer (Figure 4a, b).

\section{Statistical analysis of the bathymetric distribution}

The comparison of the bathymetric distribution of specimens of Dendronotus robustus and D. velifer which were involved in the molecular taxonomic anal- ysis (see above) reveal significant statistical differences ( $p=0.002$, Figure $4 c)$. The bathymetric data for historical specimens of $D$. velifer and for recently collected $D$. robustus demonstrate statistically significant differences ( $p<0.001$, Figure $4 c$; right lilac and left blue bars). At the same time, the bathymetric data between historical specimens of $D$. velifer and the recently collected specimens of $D$. velifer do not show any significant differences (Figure 4c). 

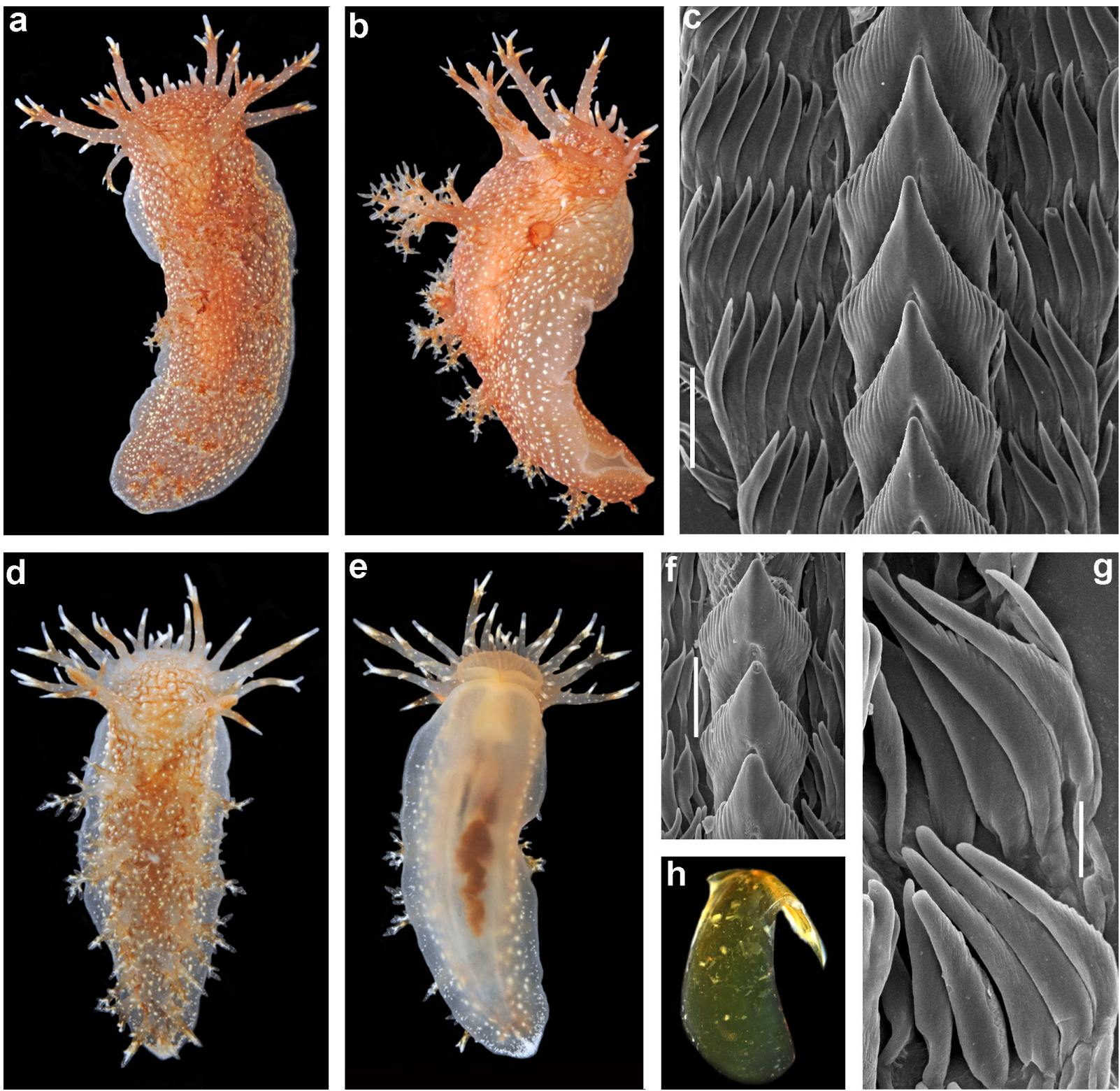

Figure 3. Dendronotus robustus specimens from the Arctic, which were utilised for the molecular study. a, b: habit of living D. robustus $35 \mathrm{~mm}$ in length, Barents Sea, dorsal and lateral views respectively (ZMMU Op-343); d, e: habit of living D. robustus $19 \mathrm{~mm}$ in length (ZMMU Op-344), Barents Sea, dorsal and ventral views, respectively; c: internal characters of Arctic D. robustus specimen ZMMU Op-343: radula of specimen ZMMU Op-344, central and lateral teeth; f-g: radula of specimen ZMMU Op-344, central and lateral teeth respectively; h: jaw of specimen ZMMU Op-343. Scale bars: c: $100 \mu \mathrm{m}$; f, g: $30 \mu \mathrm{m}$. Photographs by T. Korshunova.

\section{Discussion}

Dendronotus robustus is often considered a circumpolar and deep-water species (Robilliard, 1970; Ekimova et al., 2015). However, based on the combined distribution of all specimens it has supposedly an extremely broad range encompassing the whole Arctic fringe of
Eurasia and North America. This distributional hypothesis has never been tested using modern molecular approaches. Remarkably, the type locality of Dendronotus robustus is at an intertidal location at Grand Manan Island in the Canadian Eastern Atlantic (Verrill, 1870), whereas most specimens of supposed $D$. robustus come from considerably deeper waters, usually greater than 
Table 2. List of recently collected specimens of D. velifer (Figure $2 \mathrm{a}-\mathrm{e}$ ) and of D. robustus (Figure $2 \mathrm{j}-\mathrm{m}$ ) which were utilised for the molecular study.

\begin{tabular}{|c|c|c|c|c|c|}
\hline \multirow[t]{2}{*}{ Species } & \multirow[t]{2}{*}{ Registration } & \multirow[t]{2}{*}{ Locality } & \multirow{2}{*}{$\begin{array}{l}\text { Depth, } \\
\text { m }\end{array}$} & \multicolumn{2}{|c|}{ GenBank accession no. } \\
\hline & & & & COI & $16 S$ \\
\hline D. robustus & ZMMU Op-343 & Russia: Barents Sea & $5-10$ & KM397002 & KM397084 \\
\hline D. robustus & ZMMU Op-344 & Russia: Barents Sea & $5-10$ & KM397003 & KM397085 \\
\hline D. robustus & ZMMU Op-390-1 & Russia: Barents Sea & 13 & KM396963 & KM397045 \\
\hline D. robustus & ZMMU Op-390-2 & Russia: Barents Sea & 13 & KM396964 & KM397046 \\
\hline D. robustus & ZMMU Op-390-3 & Russia: Barents Sea & 13 & KM396965 & KM397047 \\
\hline D. robustus & ZMMU Op-390-4 & Russia: Barents Sea & 13 & KM396966 & KM397048 \\
\hline D. robustus & ZMMU Op-390-5 & Russia: Barents Sea & 13 & KM396968 & KM397051 \\
\hline D. robustus & ZMMU Op-391 & Russia: Barents Sea & 18 & KM396970 & KM397053 \\
\hline D. robustus & ZMMU Op-392-1 & Russia: Barents Sea & 19 & KM396967 & KM397049 \\
\hline D. robustus & ZMMU Op-392-2 & Russia: Barents Sea & 19 & KY996408* & KY996404* \\
\hline D. robustus & ZMMU Op-393 & Russia: Barents Sea & 17 & KM396969 & KM397052 \\
\hline D. velifer & ZMMU Op-546 & Russia: Laptev Sea & 43 & KY996409* & KY996405* \\
\hline D. velifer & ZMMU Op-547 & Russia: Barents Sea & $308-321$ & KY996410* & KY996406* \\
\hline D. velifer & ZMMU Op-348 & Russia: Kara Sea & 21 & MF685027* & KY996407* \\
\hline D. velifer & ZMMU Op-296 & Russia: Barents Sea & $135-137$ & КС660038 & - \\
\hline D. velifer & NF11 & Canada: Newfoundland & $231-212$ & KU695599 & - \\
\hline
\end{tabular}

* - sequenced for this study.

$100 \mathrm{~m}$. In spite of such obvious ecological contradictions, to assess a correct taxonomic name for the Swedish Gullmar Fjord population, we investigated both very shallow water populations previously identified as $D$. robustus from the Barents Sea and compared them with the deep-water specimens from almost the whole geographic range from North American Eastern Atlantic waters to the Arctic Laptev Sea.

\section{Integration of molecular and morphological data}

We discovered significant molecular differences between shallow-water and deep-water specimens of putative $D$. robustus. These molecular differences agree with the disparity in the colour features in the first description of true shallow-water D. robustus from the intertidal (Verrill, 1870) and the deep-water specimens. Verrill (1870: 406) described the colour of $D$. robustus as "pale greyish, thickly sprinkled with small yellow spots", whereas the colour of the deep- water Norwegian specimens, previously described by G.O. Sars (1878: 315) from 109-183 m under the name of Dendronotus velifer G.O. Sars, 1878, is a "bright reddish with varied white spots" ("Color late rufescens, punctis albidis variegates").

As shown in the present study, such molecular and morphological differences between shallow-water and deep-water specimens persist over a very large biogeographic range, from the American Eastern Atlantic to the Arctic Laptev Sea. Significantly, a molecular and morphological data set has recently become available for a deep-water specimen from off Newfoundland (Valdés et al., 2017). This specimen matches, both its external features (i.e. rather bright and uniform reddish colour) and its molecular data, with our deepwater specimens from about $100 \mathrm{~m}$ and deeper from the Barents, Kara and Laptev seas. It does not match our shallow water Barents Sea specimens, which represent a different species with more greyish to brownish-yellowish colour. Although these differences are 


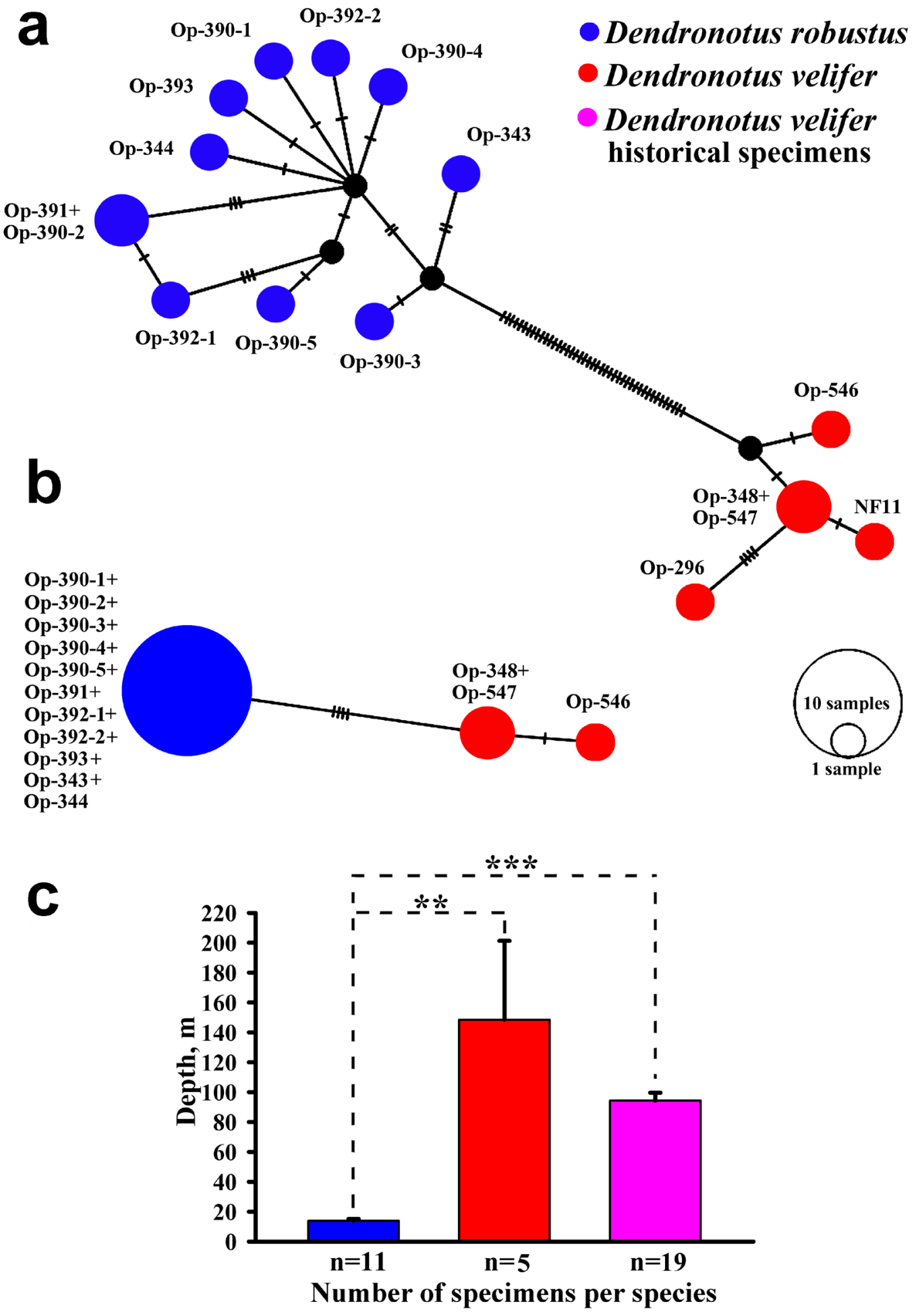

Figure 4. The haplotype networks (a-b) based on COI (a) and 16S (b) molecular data showing genetic mutations occurring within Dendronotus species. (c) Statistical test of the reliability of the bathymetic distribution patterns of D. robustus (blue bar) and D. velifer (red and lilac bars): comparision of the specimens involved in a molecular study (blue and red bars) with historical specimens (lilac bar) of $D$. velifer from Swedish and Norwegian museums. ** $\mathrm{p}<0.01$, *** $\mathrm{p}<0.001$. See text for details. 
somewhat subtle, the greyish colour mentioned in the first description of true D. robustus from the Canadian Atlantic fits with the shallow-water species from the Barents Sea (Figure 3a, b, d, e), and not with the more uniformly red colour of the deep sea $D$. velifer from the various Arctic seas, including the Laptev and Kara seas (Figure 2a, b, h-j).

Therefore, both the morphological and the molecular data clearly suggest that two species are actually confused under the name $D$. robustus in the North Atlantic Ocean - one lives in shallow water from the intertidal to approximately $20 \mathrm{~m}$ depth and the other lives deeper, at depths of $50-300 \mathrm{~m}$, most commonly at $80-150 \mathrm{~m}$. The integrative, molecular and morphological data unambiguously suggest that the shallowwater and the deep-water specimens belong to different species, and therefore we hereby restore the name Dendronotus velifer G.O. Sars, 1878 for the deepwater species and retain D. robustus for the shallowwater species. Both species share a similar body shape and a soft-bottom habitat, usually with an almost omnivorous diet (including cnidarians, which is typical of other dendronotoids, but also polychaetes and even sunken terrestrial beetles; see Roginskaya, 1990).

\section{Statistical analysis of the bathymetric distribution}

Based on robust molecular data to distinguish between the shallow and deep species from other parts of the North Atlantic Ocean (Figure 4a, b), the historical specimens from Swedish Gullmar Fjord most probably belong to the deep-water species $D$. velifer and not to the shallow water D. robustus. This is because most of the specimens from the Gullmar Fjord were found in depths of 100-118 m, and never shallower than $53 \mathrm{~m}$. This agrees with the general upper bathymetrical limit for D. velifer at 40-60 m. At some localities in the Artic seas where the layer of cold water can occur close to the surface, e.g. in the Kara Sea and the White Sea, $D$. velifer can be found in shallow depths, around 15-20 $\mathrm{m}$, thus overlapping with the potential range of $D$. robustus. However, it is important to note that the true $D$. robustus was never found in Kara and White seas, except for the subarctic Barents Sea, which is influenced by the Gulfstream. Furthermore, in the Barents Sea $D$. robustus apparently never goes down to the shallowest depth $(43 \mathrm{~m})$ reported here for $D$. velifer. Thus, despite the possibility that the lower bathymetric limit of $D$. robustus might hypothetically overlap with the upper bathymetric limit of $D$. velifer at a general scale, these two species are unlikely to occur syntopically. Also, for the correct evaluation of the taxonomic placement of the Gullmar Fjord Dendronotus specimens, it is crucial that despite specimens of $D$. velifer (having general preference for deeper waters) in some localities are able to appear much shallower (for example following by low temperatures in shallow waters in many Arctic regions, e.g. in the Kara and White seas), D. robustus has never been recorded at depths greater than $20 \mathrm{~m}$. Thus, along with morphological arguments, the results of the statistical analysis of the bathymetric distribution (Figure 4c) strongly support the hypothesis that it was D. velifer that occurred in the Gullmar Fjord and the southern Norwegian localities.

\section{Taxonomic evaluation}

Further support for the hypothesis that the Swedish deep-water specimens belong to $D$. velifer is their reddish colour (Odhner, 1907: 19). However, in the same publication Odhner (1907) listed $D$. velifer as a synonym of $D$. robustus, without any specific discussion on the issue, probably due to the similarity of the broad body in both species. But Odhner evidently omitted noting the differences in colour (reddish versus greyish-yellowish colour), and importantly also the considerable differences in bathymetric distribution (100$300 \mathrm{~m}$ versus intertidal), and hence, in ecological patterns. Previously, Bergh (1900) had also uncritically synonymised D. robustus and $D$. velifer under the former name. Furthermore, Odhner subsequently reported $D$. velifer, mostly from some deep Norwegian fjords (e.g. Sandnessjøen, Nordland fylke, June 1938, coll. O. Björlykke, 200 m, see Odhner 1939, also Odhner, 1922, 1926), under the name D. robustus. Thus, it was accepted by most of the subsequent researchers and incorporated in regional lists and identification keys (e.g. Roginskaya, 1987; Martynov and Korshunova, 2011; Ekimova et al., 2015). Apart from the differences in coloration (which compared to some other Dendronotus species actually appear to be more stable in this species pair, but still may represent some difficulties for identification in the field) and considerable differences in the molecular data (Figure 4a, b), D. robustus and $D$. velifer can also be distinguished by radular features (Appendix; Figs. 1-3). In particular, specimens of D. robustus prove to have higher central (rachidian) teeth (Figure 3c, f) and considerably more denticulated lateral teeth, especially in smaller specimens (Figure 2c, f, k). Dendronotus velifer in contrast possesses lower central teeth and less denticulated lateral teeth. The lateral teeth in larger specimens of $D$. 
velifer are almost smooth with only traces of reduced denticles on some of them (Figure 1e), whereas smaller specimens of $D$. velifer may possess more denticulated teeth, which are considerably less denticulated (Figure $1 \mathrm{j}, \mathrm{k}$ ) than in D. robustus of comparable size (Figure $3 \mathrm{~g}$ ). These data on the Swedish Gullmar specimens are remarkably consistent with the original description of D. velifer by G.O. Sars (1878: 315), wherein he mentions of the lateral teeth: "uncini utrinqve 15, laeves, vel vestigium modo indistinctum denticulorum hic et illic exhibentes" (= 15 lateral teeth, smooth with indistinct rudimentary denticles on the lateral teeth).

Dendronotus velifer also appears to have fewer dorsolateral appendages than D. robustus: even in quite a large specimen from the Laptev Sea $(49 \mathrm{~mm})$ there are only five pairs of dorsolateral appendages (Figure 2a, b), and likewise in specimens from the Gullmar Fjord, including a small specimen of $13.5 \mathrm{~mm}$ length (Figure 1a-h). In contrast, even in a subadult $(19 \mathrm{~mm})$ specimen of D. robustus (Figure 3d, e) from the Barents Sea, there are six dorsolateral processes. In the larger (35 mm) D. robustus from the Barents Sea, the number of dorsolateral appendages is seven. These data partly agree with the original descriptions of $D$. robustus and D. velifer: Verrill (1870) indicated six pairs of dorsolateral appendages in a $50 \mathrm{~mm}$ long specimen of $D$. robustus, whereas G.O. Sars mentioned five to six dorsolateral appendages for several specimens with a maximum length of $90 \mathrm{~mm}$. According to these and our data, it is likely that $D$. velifer usually has no more than five dorsolateral appendages compared to the usual six appendages of D. robustus, even found in small specimens. As an exception, large specimens of $D$. velifer may have an additional sixth appendage, whereas $D$. robustus with half the size of the largest $D$. velifer possess up to at least seven pairs. Furthermore, the frontal digitate appendages (processes) on the oral veil are relatively much longer in $D$. robustus (Figure 3a-d) than in D. velifer (Figure 2a, b, h-j). Such relative differences, after additional testing, may prove to be reliable morphological features to distinguish $D$. velifer and D. robustus.

Dendronotus velifer differs from the three other congeneric species that can occur in the same geographic area (i.e. D. frondosus (Ascanius, 1774), D. lacteus (W. Thompson, 1840), and D. niveus Ekimova et al., 2015) by its wedge-shaped body, which is considerably expanded in comparison to the more slender body that is only slightly expanded anteriorly in the other three species. Furthermore, D. velifer has a considerably broader oral veil and it lacks lateral papillae on the rhinophoral sheaths, compared to the three congeners. Internally these three species also differ from D. velifer by their radular characters. Dendronotus velifer differs from a tropical Pacific Ocean species with a similarly wide anterior body, D. patricki Stout et al., 2011, by its reddish colour with scattered white dots and stripes $(D$. patricki is uniformly pinkish to reddish brown, without any white spots on the dorsum, except for the tips of the appendages) and D. velifer also differs from $D$. patricki by the less protracted cusp of the central tooth, more numerous lateral teeth per row, and by the presence of the reduced denticles on the lateral teeth (Figure 1e, j, k). Along the Swedish western coast $D$. lacteus and $D$. frondosus are common in the subtidal zone from the surface down to 30 $m$ depth. None of these species have been confidently recorded from the deep section of the Gullmar Fjord, although the known bathymetric preferences of $D$. lacteus and D. niveus potentially allow these species to inhabit the deeper parts of the Gullmar Fjord. Should these species be found sympatrically with $D$. velifer in the Gullmar Fjord, it will be easy to distinguish them by body shape, colour and the radula. So far, true $D$. robustus has never been positively reported from the shallow areas of Norway or Sweden. Material from the Norwegian Trondheim Fjord, previously identified as D. robustus by Friele and Grieg (1901), was examined by Odhner and revised as $D$. frondosus.

\section{Species differentiation, bathymetric distribution and biogeographic range}

As shown above, the molecular analysis confirms that $D$. robustus and D. velifer are separate species, and that they are clearly differentiated by morphology. The bathymetric analysis also shows a clear separation in depth preference. The historical specimens from Gullmar Fjord have a morphology that is consistent with the recently collected Arctic D. velifer specimens and they show a clear preference to the greater depths around $100 \mathrm{~m}$. Thus, these specimens can be confidently identified as $D$. velifer. A further finding relevant for this case, is the recent report of a single specimen identified as $D$. "robustus" collected from around $200 \mathrm{~m}$ depth off the North Atlantic coast of North America (Valdés et al., 2017) that fully agrees with $D$. velifer according to our molecular analysis. Therefore, it is possible that $D$. velifer might occur in more southward locations like the Gullmar Fjord if temperature and other ecological conditions permit. The isolated population of D. velifer in the Gullmar 
Fjord could therefore possibly have been a relict population from an earlier glacial period with colder water. At that time the species could have had a more southerly distribution.

The maximum depth of the Gullmar Fjord is about $118 \mathrm{~m}$ and many of the $D$. velifer specimens were taken from the deepest section of the fjord. The deeper parts of the fjord (90-118 m), inside the sill, have fully saline water and naturally stable conditions (Svansson, 1975; Filipsson et al., 2005). In the present study it is statistically proven (Figure $4 \mathrm{c}$ ) that $D$. velifer differs significantly from $D$. robustus by its preference for greater depths and hence for lower seawater temperatures. Therefore, it can be supposed that small, statistically insignificant differences in the depth preferences between the Arctic specimens of D. velifer (Figure 4c) and the specimens from the Gullmar Fjord (Figure 4c) are due only to the depth limit of the Fjord. If the Gullmar Fjord were deeper, D. velifer would extend to depths of at least $200 \mathrm{~m}$, and beyond. Two historical findings of single specimens in the fjords of Norway the Oslo Fjord and the Hardanger Fjord - provide a link from the Gullmar Fjord in Sweden to the northwestern Norwegian coast, and further to the main range of $D$. velifer through almost all of the Arctic from the Barents to the Laptev Sea and further, to the Bering Strait.

\section{Implications for nature conservation}

The Gullmar Fjord has been impacted by bottom trawling and other disturbances since the 1900s. At about the midpoint of the fjord, close to the bay of Skår, one of Sweden's busiest ferry services has been running since the late 1960s, operating the largest car-driven car ferries in the country. During the day these ferries ply back and forth across the fjord every $20 \mathrm{~min}$. This causes constant turbulence of the bottom sediments on the slopes and, consequently has at least locally, a considerable impact on the fjord's ecosystem. This impact, together with bottom trawling for shrimps in the habitat for $D$. velifer might have caused the decline and local extinction of the species. Furthermore, at some periods during later part of the 1970s and early 1980s there were some periods of low oxygen levels in the deep trench of the fjord, which must have added stress to the organisms living there. The collections of $D$. velifer from the 1940s were in the innermost and relatively shallow sections of the fjord, in which the bottom environment could have been comparatively less affected, at least for some time, and be more stable. It is unknown if such a stability still exists in places, which may imply that a population of $D$. velifer could still be present. This would then be in parallell with that of the long-absent aeolid nudibranch Flabellina borealis (Odhner, 1922), which was recently rediscovered in the fjord (Lundin and Malmberg, 2016).

The two historical records of single specimens of $D$. velifer in the Oslo Fjord in southeastern Norway and in the Hardanger Fjord on the southwest may represent a link from the Gullmar Fjord in Sweden to the northwestern Norwegian coast. The Bunnfiorden area has a threshold at $60 \mathrm{~m}$, and an inner deep trench that goes down to $150 \mathrm{~m}$. It is adjacent to parts of the city of Oslo and its southeasters suburbs. The water in the deep trench is of poor quality, hence we can hardly expect any $D$. velifer to have survived here since the early 1900s. The locality at Sunde, in the Hardanger Fjord on the southwestern coast of Norway is close to the mouth of the fjord, and thus it has better environmental conditions.

Although we cannot report living specimens of Dendronotus velifer from the Gullmar Fjord now, this study is the first that summarises all findings of this species and the first that uses morphological, molecular and ecological evidence to assess the taxonomic position of the predominantly Arctic $D$. velifer. Such an integrative assessment is important for conservation since there is an ongoing discussion on establishing a national marine park within the Gullmar Fjord. The relatively recent record of $D$. velifer in the Gullmar Fjord would certainly strengthen the arguments in favour of a marine park to protect the whole area.

\section{Importance of natural history collections}

The present study highlights the necessity of close linkages between historical museum specimens and actual biological patterns and processes including refinement of the taxonomic placement and biogeographic ranges. Therefore, it further contributes to a general recognition of taxonomy as a central biological discipline with high integrative potential for multipurpose applications. This is not the first case in which a study of historical specimens in museum collections can be applied to retrieve past species records and to reconstruct historical base lines regarding the distribution ranges of species, which can produce relevant information for the conservation of these species and their habitats (e.g. Shaffer et al., 1998; Pyke and Ehrlich, 2010; Rainbow, 2009; Drew, 2011; Ellis et al., 2011; Hoeksema et al., 2011; Lips, 2011; Hoeksema, 2015). The historical records of the present study should stimulate researchers to survey Gullmar Fjord 
and other localities for the present occurrence of $D$. velifer and for additional rarely encountered species that may be locally threatened.

\section{Acknowledgements}

We wish to thank Mikael Thollesson (Evolutionary Biology Centre, Uppsala University), who, in the 1990s, noted the presence of Swedish specimens of the then Dendronotus robustus in the collections at GNM. We thank Anna Persson (Swedish Museum of Natural History) and Torsten Hugo Struck (Oslo Natural History Museum) for providing collection information. We would particularly like to thank O.L. Zimina for providing specimens of D. robustus and D. velifer collected in the Arctic seas. A.G. Bogdanov and G.N. Davidovich (Electron Microscopy Laboratory MSU) are thanked for support with electron microscopy. Richard Willan (Museum and Art Gallery of the Northern Territory, Australia) and two anonymous reviewers are thanked for their constructive comments on the manuscript. This study was supported by a research grant from MSU Zoological Museum (AAAA-A16-116021660077-3, for deposition of specimens) and The Russian Science Foundation (grant 14-50-00029, for the collection of specimens and molecular and morphological analyses).

\section{References}

Bergh R. 1900. Nudibranchiate Gasteropoda. The Danish Ingolf-Expedition, Copenhagen 2: 1-49.

Bertsch H. 2014. Biodiversity in La Reserva de la Biósfera Bahía de los Ángeles y Canales de Ballenas y Salsipuedes: Naming of a new genus, range extensions and new records, and species list of Heterobranchia (Mollusca: Gastropoda), with comments on biodiversity conservation within Marine Reserves. The Festivus 46: 158-177.

Bickford D, Lohman DJ, Sodhi NS, Ng PKL., Meier R, Winker $\mathrm{K}$, Ingram KK, Das I. 2006. Cryptic species as a window on diversity and conservation. Trends in Ecology and Evolution 22: $148-155$.

Drew J. 2011. The role of natural history institutions and bioinformatics in conservation biology. Conservation Biology 25 : $1250-252$.

Edgar RC. 2004. MUSCLE: multiple sequence alignment with high accuracy and high

Throughput. Nuclear Acid Research 32: 1792-1797.

Ekimova I, Korshunova T, Schepetov D, Neretina T, Sanamyan N, Martynov A. 2015. Integrative systematics of northern and Arctic nudibranchs of the genus Dendronotus (Mollusca, Gastropoda), with descriptions of three new species. Zoological Journal of the Linnean Society 173: 841-886.

Ellis SL, Incze LS, Lawton P, Ojaveer H, MacKenzie BR, et al. 2011. Four regional marine biodiversity studies: approaches and contributions to ecosystem- based management. PLoS ONE 6: e18997.

Evertsen J, Bakken T. 2005. Nudibranch diversity (Heterobranchia, Gastropoda) along the coast of Norway. Fauna Norvegica 25: 1- 52 .
Filipsson HL, Björk G, Harlandb R, McQuoidc MR, Nordberg K. 2005. A major change in the phytoplankton of a Swedish sill fjord - a consequence of engineering work? Estuarine, Coastal and Shelf Science 63: 551-560.

Friele H, Grieg JA. 1901. Mollusca III. Den Norske Nordhavsexpedition 1876-1878 28: 1-131.

Folmer O, Black M, Hoeh W, Lutz R, Vrijenhoek R. 1994. DNA primers for amplification of mitochondrial cytochrome $\mathrm{c}$ oxidase subunit I from diverse metazoan invertebrates. Molecular Marine Biology Biotechnology 3: 294-299.

Furfaro G, Picton B, Martynov A, Mariottini P. 2016. Diaphorodoris alba Portmann \& Sandmeier, 1960 is a valid species: molecular and morphological comparison with D. luteocincta (M. Sars, 1870) (Gastropoda: Nudibranchia). Zootaxa 4193: 304-316.

Garcia-Mendéz K, Camacho-Garcia YE. 2016. New records of heterobranch sea slugs (Mollusca: Gastropoda) from Isla del Coco National Park, Costa Rica. Revista de Biología Tropical 64 (Suppl. 1): S205-S219.

Goodheart JA, Bazinet AL, Collins AG, Cummings MP. 2015. Relationships within Cladobranchia (Gastropoda: Nudibranchia) based on RNA-Seq data: an initial investigation. Royal Society Open Science 2: 150-196.

Hayward PJ, Ryland JS. 2017. Handbook of the marine fauna of north-west Europe. Second edition. Oxford University Press, Oxford

Hoeksema BW. 2015. Latitudinal species diversity gradient of mushroom corals off eastern Australia: a baseline from the 1970s. Estuarine, Coastal and Shelf Science 165: 190-198.

Hoeksema BW, van der Land J, van der Meij SET, van Ofwegen LP, Reijnen BT, van Soest RWM, de Voogd NJ. 2011. Unforeseen importance of historical collections as baselines to determine biotic change of coral reefs: the Saba Bank case. Marine Ecology 32: 135-141.

Jensen K R., Knudsen J. 1995. Annotated checklist of recent marine molluscs of Danish waters. Jorgen Knudsen, Copenhagen.

Katz PS. 2016. Evolution of central pattern generators and rhythmic behaviours. Philosophical Transactions of the Royal Society B 371: 20150057.

Korshunova T, Sanamyan N, Zimina O, Fletcher K, Martynov A. 2016. Two new species and a remarkable record of the genus Dendronotus from the North Pacific and Arctic oceans (Nudibranchia). ZooKeys 630: 19-42.

Korshunova T., Martynov A., Bakken T., Picton B. 2017. External diversity is restrained by internal conservatism: New nudibranch mollusc contributes to the cryptic species problem. Zoologica Scripta, doi 10.1111/zsc.12253.

Kumar S, Stecher G, Tamura K. 2016. MEGA7: Molecular evolutionary genetics analysis version 7.0 for bigger datasets. Molecular Biology and Evolution 33: 1870-1874.

Lips KR. 2011. Museum collections: mining the past to manage the future. Proceedings of the National Academy of Science of the United States of America 108: 9323-9324.

Lundin K, Malmberg K. 2016. Nya fynd av nakensnäckor vid svenska västkusten. Fauna och Flora 111: 11-13.

Malmberg K, Lundin K. 2015. Svenska nakensnäckor. Waterglobe Productions, Halmstad.

Martynov A, Korshunova T. 2011. Opisthobranch molluscs of the seas of Russia. A colour guide to their taxonomy and biology. Fiton, Moscow. 
Martynov A, Hasegawa K, Korshunova T. 2017. The Japanese Red Data book marine mollusk Japonacteon nipponensis and a Japonacteon population from Russia belong to the same species: Molecular evidence and recommendations for conservation. Global Ecology and Conservation 9: 82-89.

Mehrotra R, Scott CM. 2016. Species inventory of sea slugs (Gastropoda: Heterobranchia) for Koh Tao, Thailand, with 25 first records for Thai waters. Marine Biodiversity 46: 761-771.

Nimbs MJ, Larkin M, Davis TR, Harasti D, Willan RC, Smith SDA. 2016. Southern range extensions for twelve heterobranch sea slugs (Gastropoda: Heterobranchia) on the eastern coast of Australia. Marine Biodiversity Records 9: 27.

Nuzzo G, Ciavatta ML, Kiss R., Mathieu V., Leclercqz H, Manzo E, Villani G, Mollo E, Lefranc F, D’Souza L, Gavagnin M, Cimino G. 2012. Chemistry of the nudibranch Aldisa andersoni: Structure and biological activity of phorbazole metabolites. Marine Drugs 10: 1799-1811.

Odhner N. 1907. Northern and Arctic invertebrates in the collection of the Swedish state museum. Kungliga Svenska Vetenskapsakademiens Handlingaar 41: 1-114.

Odhner N. 1922. Norwegian Opisthobranchiate Molusca in the collections of the zoological museum of Kristiania. Meddelelser fra Det Zoologiske Museum Kristiania 1: 1-47.

Odhner N. 1926. Nudibranchs and lamellariids from the Trondhjem fjord. Det Kongelige Norske Videnskabers-Selskabs Skrifter 2: 1-36.

Odhner N. 1939. Opisthobranchiate Mollusca from the western and northern coast of Norway. Det Kongelige Norske Videnskabers-Selskabs Skrifter 1: 1-93.

Padula V, Araújo AK, Matthews-Cascon H, Schrödl M. 2014. Is the Mediterranean nudibranch Cratena peregrina (Gmelin, 1791) present in the Brazilian coast? Integrative species delimitation and description of Cratena minor $\mathrm{n}$. sp. Journal of Molluscan Studies 80: 575-584.

Palumbi SR, Martin AP, Romano S, McMillan WO, Stice L, Grabowski, G. 2002. The simple fool's guide to PCR. University of Hawaii, Honolulu.

Picton BE, Morrow C. 1994. A field guide to the nudibranchs of the British Isles. Immel Publishing, London.

Puslednik L, Serb JM. 2008. Molecular phylogenetics of the Pectinidae (Mollusca: Bivalvia) and effect of increased taxon sampling and outgroup selection on tree topology. Molecular Phylogenetics and Evolution 48: 1178-1188.

Pyke GH, Ehrlich PR. 2010. Biological collections and ecological/environmental research: a review, some observations and a look to the future. Biological Reviews 85: 247-266.

Rainbow PS. 2009. Marine biological collections in the 21st century. Zoologica Scripta 38 (Suppl. 1): 33-40.

Robilliard GA. 1970. The systematics and some aspects of the ecology of the genus Dendronotus. The Veliger 12: 433-479.

Roginskaya IS. 1987. Order Nudibranchia Blainville, 1814. In: Molluscs of the White Sea. Keys to the Fauna of USSR 151: 155-201.

Roginskaya IS. 1990. Additional data on the food and feeding of Dendronotus robustus Verrill, 1879 (Nudibranchia: Dendronotidae) from Dvinsky Bay of the White Sea. In: A. P. Kuznetsov (eds) Feeding and bioenergetics of marine bottom invertebrates. Academy of Sciences of the U.S.S.R., P. P. Shirshov Institute of Oceanology, Moscow, pp. 93-110, 158.

Sars GO. 1878. Bidrag til kundskaben om Norges Arktiske fauna. I. Mollusca Regionis Arcticae Norvegiae. Oversigt Over de I Norges Arktiske Region Forekommende Blфddyr. Brøgger, Christiania.

Shaffer HB, Fisher RN, Davidson C. 1998. The role of natural history collections in documenting species declines. Trends in Ecology and Evolution 13: 27-30.

Svansson A. 1975. Physical and chemical oceanography of the Skagerrak and the Kattegat. I Open sea conditions. Fishery Board Sweden, Institute of Marine Research.

Thollesson M. 1998. Discrimination of two Dendronotus species by allozyme electrophoresis and the reinstatement of Dendronotus lacteus (Thompson, 1840) (Nudibranchia, Dendronotoidea). Zoologica Scripta 27: 189-195.

Thompson TE, Brown GH. 1984. Biology of opisthobranch molluscs. Vol. 2. The Ray Society Publications, London.

Valdés A, Murillo FJ, Mccarthy JB, Yedinak N (2017) New deep-water records and species of North Atlantic nudibranchs (Mollusca, Gastropoda: Heterobranchia) with the description of a new species. Journal of Marine Biological Association of the United Kingdom 97: 303-319.

Verrill AE. 1870. Contributions to zoology from the museum of Yale College. $\mathrm{N}^{\circ}$ 8. - Descriptions of some New England Nudibranchiata. American Journal of Science and Arts 50: 405-408

Received: 11 August 2017

Revised and accepted: 21 November 2017

Published online: 22 December 2017

Editor: B.W. Hoeksema 


\section{Appendix 1}

Morphological analysis and redescription of Dendronotus velifer G.O. Sars, 1878

A syntypic specimen (Figure 1n-o) of D. velifer from the type locality in the Barents Sea (Vads $\varnothing$, Norway) in the collection at the Oslo Natural History Museum (Accession number 16174) is hereby designated as lectotype, to fix and stabilize the name. This is the best preserved specimen of the original series collected by G.O. Sars on which the original description of $\mathrm{D}$. velifer was based. A short redescription based on both this lectotype and additional specimens, is given below.

Dendronotus velifer G.O. Sars, 1878

Dendronotus velifer G.O. Sars, 1878: 238-239, pl. 28, Figure 2, pl. 15, Figure 4.

Dendronotus robustus sensu Bergh 1900 - Odhner 1907 (non Verrill 1870).

Dendronotus robustus auct. Partim $=$ mixture of $D$. robustus and D. velifer.
Body broad, preserved specimens ranged from 13.5$49 \mathrm{~mm}$ (up to $90 \mathrm{~mm}$ in first description) in length (Figures 1,2). 6-12 main branched appendages on oral veil, 4-5 appendages on rhinophoral stalks, 12-15 rhinophoral lamellae, small papilla lateral to rhinophore either present or absent, 4-5 pairs of dorsolateral appendages present (90-mm specimen has sixth rudimentary pair according to first description), 30-35 distinct lip papillae. Dorsolateral appendages with relatively short primary stalk, moderately branched secondary branches and elongate tertiary branches (Figure 1a, f). Length of dorsal processes of jaws approximately one-third total length of jaw (Figures 11; 2). Masticatory border of jaw with fine denticles. Radular formula: 29-36 × 3-13.1.13-3 (up to 15 lateral teeth in first description). Central (rachidian) tooth strongly denticulated and bearing up to 26 distinct denticles (Figures 1d, i; 2c, f, k). Denticles with deep furrows. Lateral teeth short, slightly curved, smooth or sometimes bearing 1-7 rudimentary denticles (Figures 1e, j, k; 2g, 1, m). Ampulla 2-looped. Prostate discoidal, consisting of alveolar glands. Distal part of vas deferens moderate in length, transiting to long, thin, copulatory organ. Bursa copulatrix large, rounded, elongated, seminal receptaculum placed distally. 